\title{
CLIMETO-CYLIC IMMIGRATIONS WITH DECLINING POPULATION OF WILD HONEYBEE, APIS DORSATA F. IN CHITWAN VALLEY, NEPAL
}

Suroj Pokhrel, PhD'

\begin{abstract}
A general survey was conducted to investigate the phenomena of seasonal immigration, aggregation and staying of Apis dorsata Fab. colonies in Chitwan valley, Nepal in 2003/04. The primary immigration of small colonies occurred during November-December in Southern areas and secondary type mainly from site shifting of the large colonies towards north of Chitwan valley in January-February and smaller colonies through swarming in March-April respectively. Maximum colonies aggregated in March with maximum staying of eight months. Colonies aggregation declined by 54\%, 50\% and 100\% in May, June and July and the period of colony staying declined by $25 \%$ as compared to previous years. The causes of population decline were: bad weather, predators and parasites, honey hunting, increasing pesticide use, declining bee pasture and inter species competition with exotic $A$. mellifera L. Policy declaration with suitable programs for the conservation of native wild honeybee, A. dorsata in its indigenous habitat for the maintenance of biodiversity and raising the crop productivity is necessary.
\end{abstract}

Key words: Aggregation, bee pasture, biodiversity, colony staying, honey hunting, immigration, nesting site, swarming.

\section{INTRODUCTION}

Honeybee diversity in Hindu Kush Himalayan (HKH) region consists of Apis cerana $\mathrm{F}$., $A$. dorsata F., A. florea F. and A. laboriosa Smith and exotic A. mellifera L. Among these honeybees $A$. dorsata is a wild, open nesting and single comb building honeybee and is a natural pollinator of several cultivated and wild plants in Asia (Atwal, 1970; Maun and Gurdip, 1983; Singh, 2000). They are distributed throughout the foothills, Terai and inner Terai of Nepal. Their nesting sites are tall trees, buildings, and water towers with available food resources (Lindauer, 1956: Morse and Benton, 1967; Reddy, 1980, Hadorn, 1984; Pokhrel, 2005). However, the biology, aggregation, migration and immigration of this species are poorly understood (Roepke, 1930; Lindauer, 1956; Morse and Benton, 1967; Koeniger and Koeniger, 1980; Seeley et al,. 1982; Hadorn, 1984; Sihag, 1998;). The members of this species are furious and attack in mass for defense (Maschwitz, 1963; Frish, 1967; Morse et al., 1967; Koeniger et al., 1979). They are good honey collectors (Thakar and Tonapi, 1961; Singh, 1980), and therefore, important source of honey in Nepal (Shrestha, 2001). The role of these bees as crop pollinators to augment national income through increased bio-diversity and crop production has been forgotten. In addition, honey hunting, destruction of the nesting sites and the natural pasture (forest), increasing trend of pesticide use for crop protection, reduction of cultivated bee flora and the rapid multiplication of $A$. mellifera colonies in its natural habitat in Chitwan valley Nepal, in nineties, pushed this species on the verge of extinction (Shrestha, 2001; Pokhrel, 2005; Pokhrel, 2006; Pokhrel, 2008; Pokhrel, 2009). Thus, study on the natural biology and cause of decline of $A$. dorsata population in its natural habitat in Chitwan valley was necessary. The objective of the study was to investigate the phenomena of seasonal immigration, aggregation and staying of $A$. dorsata colonies in Chitwan valley, Nepal.

1 Program Director, Crop Development Directorate, Department of Agriculture, Nepal, surojpokhrel@yahoo.com 


\section{MATERIALS AND METHODS}

The study was carried out in Chitwan district (inner Terai) in central Nepal. Sites selected for the study were the man-made structures and Bombax trees, which had the previous history of having this bee colonies nesting onto them in aggregate of 3-30 colonies on a single structure/tree at Sukranagar, Mangalpur, Yagapuri, Narayanghat, Aaptari and Bharatpur. All the sites were at 350 metres above sea level. Study was carried out throughout the year, starting from May 2003 to July 2004.

Survey of the nesting sites was carried out at monthly interval to find out the seasonal immigration of $A$. dorsata colonies in Chitwan. Observations were recorded every month on the dates of immigration and number of colonies nesting at particular sites (Sukranagar, Mangalpur, Yagapuri, Narayanghat, Aaptari and Bharatpur) and absconding. Weather data (temperature, humidity and rainfall) were collected from National Maize Research Program, Rampur.

EXCEL software was used to tabulate collected data, to prepare necessary tables, graphs and figures and to calculate means, variance and standard errors.

\section{RESULTS}

\section{IMMIGRATION SEASON}

November was the beginning month of immigration of $A$. dorsata colonies in Chitwan. The first immigration site noticed was Sukranagar (near by Chitwan National Park) followed by Yagyapuri (Horticulture Farm). Out of five sites observed in Chitwan, the immigration was continued during winter, spring and ended by early summer. In November, there were all together 12 colonies, 9 in Sukranagar and 3 in Yagyapuri. The number increased by $66.7 \%$ in December, which decreased in the winter by $60.0 \%$ and increased again in spring by $225.0 \%$.

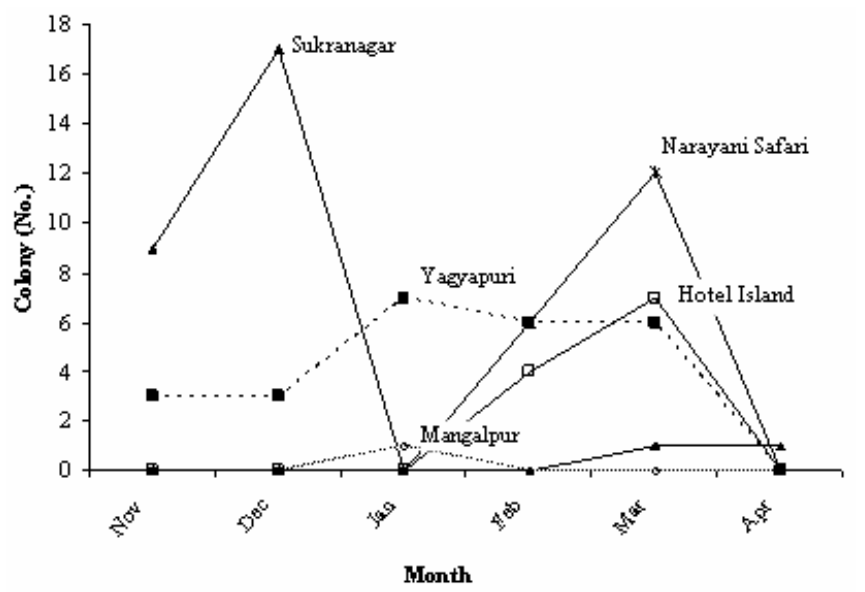

Of the total colonies immigrated Sukranagar, $\quad 92.8 \%$ occurred in NovemberDecember $(\mathrm{N}=26)$ and the rest in March-April ( $\mathrm{N}=2)$. Yangapuri was only a site of continuously immigrating colonies for five months from November to March. Immigration of the colonies in Mangalpur occurred only in January and in Bharatpur (Narayani Safari and Hotel Island) in FebruaryMarch (Fig.1).

Fig. 1: Immigration of $A$. dorsata colonies in different locations, Chitwan, 2003/04

The immigration was mainly of two types: primary and secondary immigration.

The colonies from a long distance flight arrived to the southern area of the Chitwan, near the Chitwan National Park where the early mustard, Brassica spp. and buckwheat, Fagopyrum esculentum Moench bloomed earlier in November-December. Of the total colonies $(\mathrm{N}=83), 38.6 \%(\mathrm{~N}=32)$ were the primary immigrant colonies. Over $80.0 \%$ of the primary observed immigrant (early in-coming) colonies from long distance nested at a 
private building at Bishalchock, Sukranagar and the rest nested on the water tower, Yagyapuri (Fig.1).

Secondary immigration was of two types: site shifting and swarming.

Out of the total colonies ( $\mathrm{N}=32$ ) immigrated during November-December in Chitwan, $52.0 \%$ $(\mathrm{N}=17)$ shifted their nesting sites in January-February. In a total of five locations, incoming colonies $(\mathrm{N}=83)$, the secondary immigrants through temporary site shifting were $44.6 \%$ $(\mathrm{N}=37)$.

Secondly, about one-forth of the colonies immigrated in November-December produced 4-7 queen cells per colony and swarmed in late February. Nearly $17 \%(\mathrm{~N}=14)$ colonies immigrated from swarming in February-March (Fig.1). Both the secondary type of immigrants spread to water tower at Yagyapuri, Bombax tree at Hotel Narayani Safari and Hotel Island at Bharatpur, and private building at Mangalpur.

\section{NESTING SITE}

Colonies of $A$. dorsata preferred non-disturbed previous nesting sites. They denied using white washed building at Narayanghat and the standing dead Bombax tree at Aaptari. The private building at Bishalchok, Sukranagar was most preferred due to the least disturbance and being near by the Chitwan National Park where mustard, Brassica spp. and buckwheat, F. esculentum bloomed earlier in November. They nested on tall water towers (Fig.2 and 3), Bombax trees and taller buildings at different locations. The private building at Bishalchok, Sukranagar was most preferred due to the least disturbance and being near by the Chitwan National Park where mustard, Brassica spp. and buckwheat, F. esculentum bloomed earlier in November. They nested on water towers, Bombax trees and taller buildings at different locations.

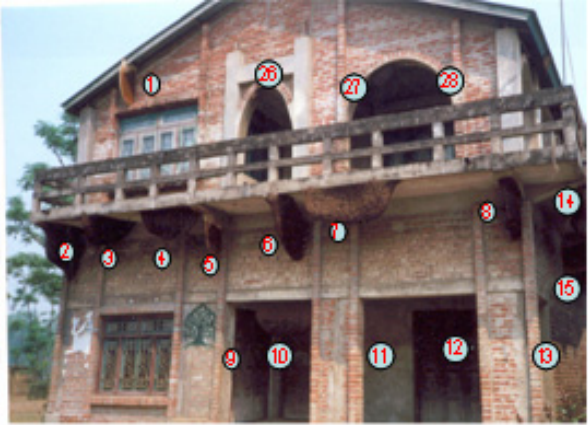

Fig. 2: Colonies nesting on a non-disturbed building at Sukranagar, Chitwan, 2003/04

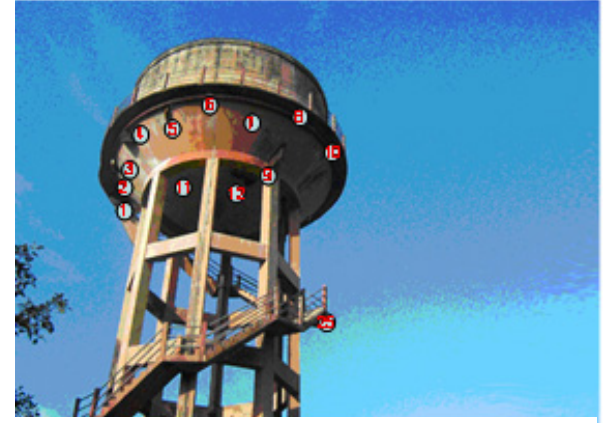

Fig. 3: Colonies nesting on a non-disturbed water tower at Yagyapuri, Chitwan, 2003/04

\section{DECLINING RATE OF COLONY IMMIGRATION AND AGGREGATION}

The highest number of $A$. dorsata colonies $(\mathrm{N}=67)$ aggregated during March at all locations except at Sukranagar where the nesting colonies were the highest $(\mathrm{N}=26)$ in December. The colony number severely decreased after March ending in October in 2003 and in July in 2004. The bee colonies at Sukranagar, Yagyapuri and Hotel Island left in July; however, in Narayani Safari they left two months earlier i.e. in May 2004. In disturbed locations (Aaptari and Pradhan Stationary) in Narayanghat, the maximum number of the colonies was observed in March ( $\mathrm{N}=7)$ in 2003 and all the colonies left by September, and did not return in 2004 (Fig.4). 

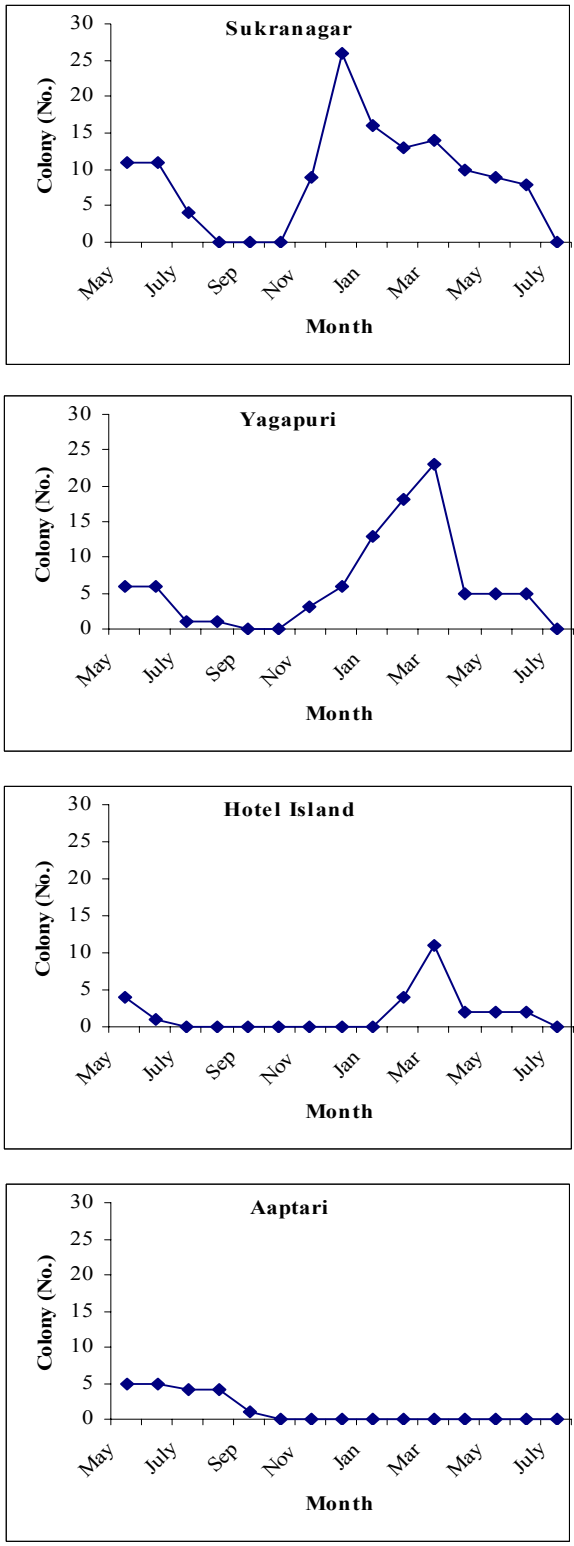
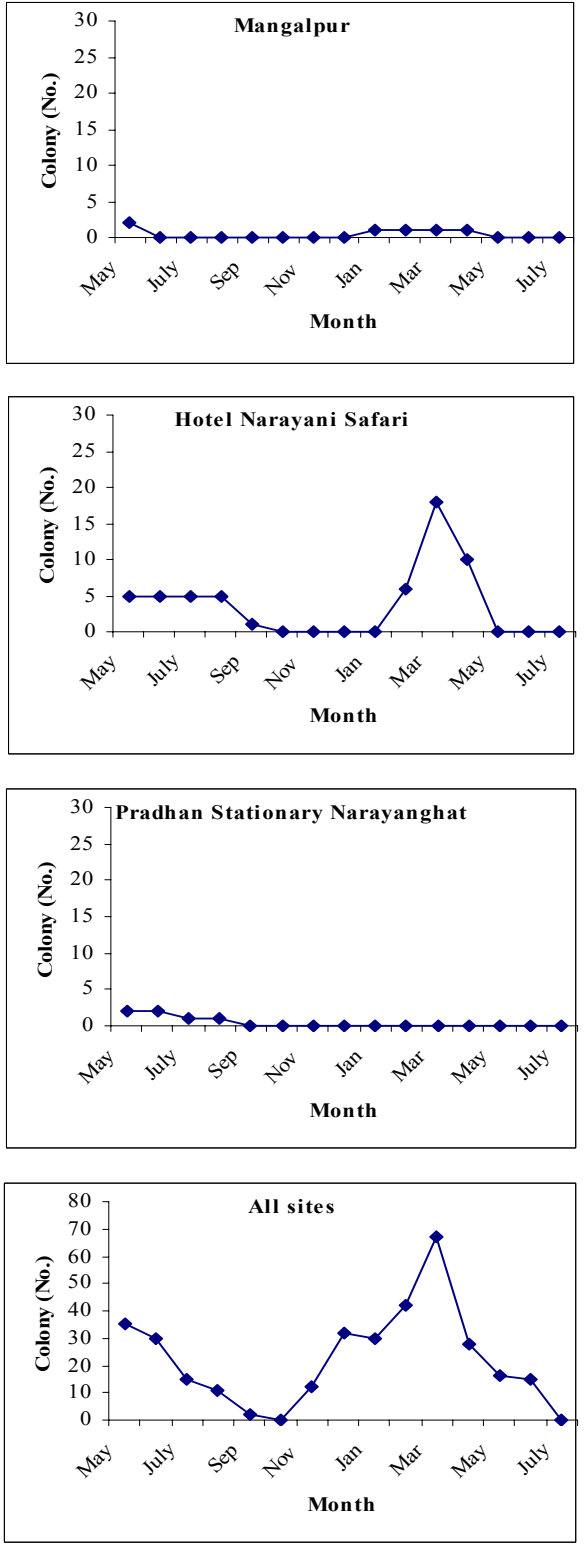

Fig. 4: Aggregation of $A$. dorsata colonies at different sites, Chitwan, 2003/04

\section{DECLINING RATE OF COLONY AGGREGATION AND PERIOD OF STAYING}

The number of $A$. dorsata colonies aggregated at different locations of Chitwan declined by $54.0 \%, 50.0 \%$ and $100 \%$ in May, June and July in 2004 compared to 2003. All the colonies left three month earlier (July) in 2004 as compared to 2003 (Fig.5). It was declined at Sukranagar by $18.2 \%, 27.3 \%$, and $100 \%$ in May, June and July, respectively, in 2004 . Bee 
colonies leaving their occupied sites differed 1-5 months at different locations, i.e. one month earlier at Mangalpur, two months at Yagyapuri and five months at Narayani Safari. The reason behind this might be environmental and climatic, and increased farming of the exotic honeybee, A. mellifera in Chitwan valley.
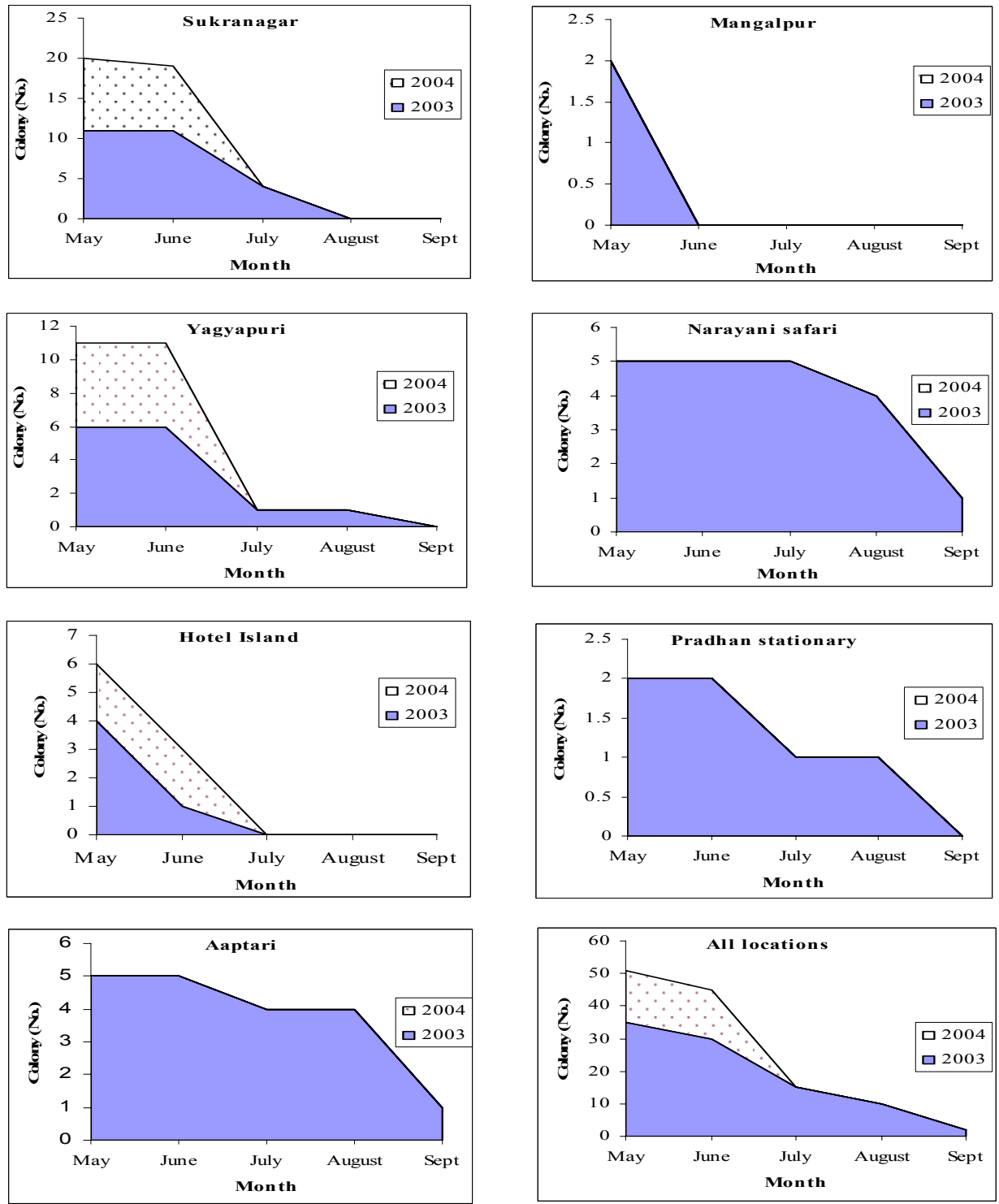

Fig. 5: Apis dorsata colonies staying during May-September in Chitwan, 2003/04

\section{CORRELATION BETWEEN THE PARAMETERS}

All parameters except initial colony size $(r=-0.211)$ with colony immigration were positively correlated with each other (Table 1). Aggregation of $A$. dorsata colonies positively 
correlated with immigration $(r=0.473)$, initial colony size $(r=0.307)$, and colony migration $(r=0.263)$. Similarly, colony migration was positively correlated with colony immigration $(r=0.258)$, colony aggregation $(r=0.263)$, colony growth rate $(r=0.070)$, and initial colony size $(r=0.141)$.

Table 1: Correlation between the parameters of A.dorsata colony migration in Chitwan, 2005.

\begin{tabular}{lcccc}
\hline \multicolumn{1}{c}{ Parameter } & $\begin{array}{c}\text { Colony } \\
\text { immigration } \\
\text { (No.) }\end{array}$ & $\begin{array}{c}\text { Colony } \\
\text { aggregation } \\
\text { (No.) }\end{array}$ & $\begin{array}{c}\text { Initial } \\
\text { colony } \\
\text { size }(\mathrm{cm} 2)\end{array}$ & $\begin{array}{c}\text { Migration } \\
\text { (No.) }\end{array}$ \\
\hline Colony immigration & 1.000 & 0.473 & -0.211 & 0.258 \\
Colony aggregation & 0.473 & 1.000 & 0.307 & 0.263 \\
Initial colony size & -0.211 & 0.307 & 1.000 & 0.141 \\
Migration & 0.258 & 0.412 & 0.141 & 1.000 \\
\hline
\end{tabular}

\section{DISCUSSION}

Three cyclic immigrations of the $A$. dorsata colonies occurred in November-December, January-February, and February-March in Chitwan, Nepal. The primary immigration of $38.6 \%$ very small colonies $(591.8 \mathrm{~cm} 2$ and $549.8 \mathrm{~cm} 2)$ occurred in November-December from the long distance flight. In January-February, the secondary immigration $(44.6 \%, \mathrm{~N}=37)$ of the larger colonies $(2302.8 \mathrm{~cm} 2$ and $1188.6 \mathrm{~cm} 2)$ was through temporary site shifting and nearly $17.0 \%(\mathrm{~N}=14)$ much smaller $(225-713 \mathrm{~cm} 2)$ colonies spread from swarming in MarchApril. Shrestha (2001) reported that most of them immigrated in Chitwan in November. The returning time of this bee in the upland of Srilanka and in Banglore, India was little earlier i.e. at the starting of dry period (October-December) (Koeniger and Koeniger, 1980) but it was late at the end of February in Mae Tung Ting and Mae Hong Son, Thailand. Hadorn (1984) observed only two cyclic immigrations of 2-3 months in Sumatra and Thapa (1998) observed two peaks of reoccupation and abandonment of nest sites in Chiang Mai, Thailand, first in November and second in January-February. The first two immigrations were similar with as explained by Thapa (1998) and Shrestha (2001). In Chitwan, additional third immigration was observed in March-April, which was from queen rearing during favorable season in February and swarming during March-April, when maximum number of bee flora were available $(\mathrm{N}=96)$.

The honeybee colonies nested on tall water towers, Bombax trees, and taller buildings at different locations in Chitwan. The first site of immigration was in south, near Chitwan National Park and around a horticulture farm in South-west of Chitwan. They preferred nondisturbed previous nesting sites near fields having early crop of mustard, Brassica spp. and buckwheat, Fagopyrum esculentum Moench blooming in November-December. They denied using white washed buildings and standing dead Bombax trees. Lindauer (1956), Morse and Benton (1967), Reddy (1980) and Seeley et al. (1982) also found the similar, non disturbed nesting sites of $A$. dorsata throughout South and South-east Asia. Mardan (1989) and Crane (1990) explained the nest site chosen by $A$. dorsata swarms for nesting was usually not directly exposed to wind currents and partially sheltered. Swarms closer to the old nest sites got first opportunity to occupy the protective nest sites and also exploited natural and cultivated flora for their survival, growth and development.

Colony aggregation was up to 28 at a private building near Chitwan National Park, 25 on a water tower at Horticulture Farm, and 18 on a Bombax tree at Hotel Narayani Safari. Aggregation of these colonies started from November, reached the highest in March $(\mathrm{N}=67)$. Aggregation of 69 colonies on a single tree and 72 on a water tower was reported in Thailand and Nepal, respectively (Wongsiri et al., 1996; Thapa, 1998). Shrestha (2001) reported 31 colonies nesting (as close as $46 \mathrm{~cm}$ apart) on a water tower at the Institute of Agriculture and Animal Science at Rampur in 2000. The aggregation of these colonies on a tree/structure has been reported from 30 to 150 (Roepke 1930; Lindauer 1956; Morse and 
Benton 1967; Koeniger and Koeniger 1980; Seeley et al., 1982; Hadorn 1984). Such aggregations of colonies was for the availability of the drones for mating (Singh, 1962; Koeniger and Koeniger, 1980; Seeley et al., 1982; Mardan, 1989; Koeniger et al., 1994; Oldroyd et al., 1996; Wongsiri et al., 1996;), for reducing predation risk and accelerating out-breeding (Moritz, 1985). Presumably, aggregation of numerous colonies might be for enhancing mutual defense (Brock and Riffenburg, ; 1960 Shrestha, 2001).

The trend of $A$. dorsata colony immigrating and aggregating in Chitwan was declined by $54 \%, 50 \%$ and $100 \%$ in May, June, and July 2004 respectively compared to 2003 . The reason behind can be environmental, agricultural and the biological. Rapid multiplication of exotic honeybee, A. mellifera L. reduction on the area of bee crops, i.e. mustard, deforestation, pesticide poisoning and predation of the colonies might be the causes. Pokhrel 2005, 2006, 2008 and 2009) agreed on these causes of $A$. dorsata population decline. Shrestha (2001) and Pokhrel (2006, 2008 and 2009) recommended conservation and protection from factors or activities bringing about their devastation or pushing them towards the course of extinction from their habitat. Hadorn (1984) and Schmidt et al. (1985) also explained extensive predation of $A$. dorsata, however, the impact on the species was smaller than the destruction of the primary forests with its tall trees in its habitat.

Seasonal immigration of $A$. dorsata colonies coincided with lower rainfall, availability of bee flora and low pest prevalence in Chitwan. Thus, it was mainly due to climato-cyclics and food availability and vice versa for their absconding/long distance migration. Thapa (1998) in Thailand also found positive correlation of $A$. dorsata migration with predators, parasites, temperature, rainfall, wind speed and physical disturbances and negative correlation to the relative humidity. Wongsiri et al. (1996) also found seasonal and cyclic migration of $A$. dorsata colonies in Thailand to exploit new resources. Oldroyd et al. (1996) described the reason of seasonal and cyclic migration and it was for to increase colony fitness by improved food availability, enhanced out-breeding and reduced brood-parasite pressures. Terai of Chitwan valley enriched with bee flora only in winter and spring, where food and nesting sites also are available. Such sites are feasible for $A$. dorsata migration as reported by Hadorn (1984).

\section{CONCLUSION AND RECOMMENDATION}

Earlier immigration of the primary immigrants' colonies in Sukranagar and Yangapuri was mainly on the non-disturbed nesting sites and earlier availability of the food sources. Secondary immigration in all the sites was from temporary site shifting and through swarming. The trend of colonies immigration and the period of colony staying declined year after year due to climate change, bad weather, increasing pesticide use for crop production, honey hunting, declining pasture both in forest and agro-ecosystem and inter species competition with exotic honeybee, A. mellifera L. in Chitwan. Conservation of $A$. dorsata in its traditional habitat for the maintenance of biodiversity and raising the crop productivity, for which promotion of bee pasture both in forest and agro ecosystem, prevention of pesticide poisoning, reduction of house bee colonies and prevention of honey hunting is necessary.

\section{REFERENCES}

Atwal, A.S. 1970. Insect pollinators of crops. Punjab Agric. Univ. Press, Ludhiana, India.

Brock, V. and R. Riffenburg. 1960. Fish schooling: A possible factor in reducing predation. J. Conc. Perno Int. Export. Man., 25:307-317.

Crane, E. 1990. Bees and beekeeping: Sciences, practice and world resources. Heinemenn Newnes, Oxford, UK. 274 pp.

Frisch, K.V. 1967. The dance language and orientation of bees. In: Morse R.A. and F.M. Laigo (eds.). 1969. Apis dorsata in the Philippines. The Beknap Press, Harvard Univversity,. Cambridge, USA 93 pp. 
Hadorn, H. 1984. Betrachtungen liber wilde Bienen in Sumatra. Schweiz Bienenztg. 1984:309-314. Apis Arten mellifera, cerana, florea and dorsata. Proc. Intl. IUSSI Congr., 7:151-153.

Koeniger, N. and G. Koeniger. 1980. Observations and experiments on migration and dance communication of Apis dorasata in Sirlanka. J. Apic. Res., 19:21-34.

Koeniger, N., G. Koeniger, S. Tingek, A. Kalitu and M. Mardan. 1994. Drones of Apis dorsata (Fab. 1793) congregate under the canopy of tall emergent trees in Borneo. Apidiologie., 25: 249-264.

Koeniger, N., J. Weiss and U. Maschwitz. 1979. Alarm pheromones of the sting in the genus Apis. J. Insect. Physiol., 25: 467-476.

Lindauer, M. 1956. Uber die Verstandigung bei indischen Bienen. Z. Vgl. Physiol., 38:521-557.

Mardan, M. 1989. Thermoregulation in the Asiatic giant honeybee Apis dorsata F. (Hymenoptera: Apidae). Ph.D. dissertation. Univ. of Guelph, Guelph. 169 pp.

Maschwitz, U. W. 1963. Gefahrenlarmstoffe und Gefahrenalamierung bei soizialen Hymenoptera. Z. Vgl. Physiol., 47: 596-695.

Maun, G. S. and S. Gurdip. 1983. Activity and abundance of pollinators of plums at Ludhiana (Punjab). American Bee J., 123: 595.

Morit, R.F.A. 1985. The effects of multiple mating on the worker queen conflict in Apis mellifera L. Behav. Eco. Sociobiol., 16: 375-377.

Morse, R.A., D.A. Shearer, R. Boch and A.W. Benton. 1967. Observations on alarm substances in the genus Apis. J. Apic. Res., 6: 113-118.

Oldroyd, B.P., A.J. Smolenski, J.M. Comuet, S. Wongsiri, A. Estoup, T. E. Rinderer and R. H. Crozier. 1996. Levels of polyandry and intercolonial genetic relationships in Apis dorsata (Hymenoptera: Apidae). Ann. Entomol. Soc. Am., 89: 276-283.

Pokhrel, S. 2005. Behavior and Management of Domesticated and Wild honeybees (Apis spp.) in Chitwan, Nepal. Ph.D. dissertation. Tribhuvan University. 240 p.

Pokhrel, S. 2005. Inter species competition of Apis dorsata Fab. and possible effects on bio-diversity in Chitwan, Nepal (in Nepali). Chitraban., 5(2):40-43.

Pokhrel, S. 2008. The ecological problems and possible solutions of beekeeping in hills and terai of Chitwan, Nepal. The Journal of Agriculture and Environment, 9: 23-33.

Pokhrel, S. 2009. Climate Change, Inter Species Competition of Honeybees and possible effects on biodiversity (in Nepali). Hamro Sampada, 9(1):29-32.

Reddy, C.C. 1980. Studies on the nesting behavior of Apis dorsata F. Intl. Conf. Apic. Trop. Climate, 2: 391-397.

Roepke, W. 1930. Beobachtungen an indishen Honigbienen insbesondere on Apis dorsata Meded Landbounwhooge-School Wageninger, 34:1-28.

Schmidt, J.O., P.I. Schmidt and C. K. Starr. 1985. Investigating the giant honeybee, Apis dorsata, in Sabah. Am. Bee J., 125: 749-751.

Seeley, T. D., R.H. Seeley and P. Akratanakul. 1982. Colony defense strategies of the honeybee in Thailand. Ecol. Monogr., 52:43-63.

Shrestha, J. B. 2001. Investigation of the parasitic mite, Tropilaelaps clareae Delfinado and Baker, and its host, Apis dorsata Fab., in Chitawan Nepal. Master's Thesis. Tribhuvan University, Institute of Agriculture and Animal Science. Rampur, Chitwan. 79 pp.

Sihag, R. C. 1998. Eco-biology of the giant honeybee (Apis dorsata) in semi-arid sub-tropical climates of India. In: M. Mastsuma, L.R. Verma, S. Wongsiri, K.K Shrestha (eds.), Asian bee keeping: Progress of research and development. Oxford \& IBH pub. Co. Pvt. Ltd. pp.50-52.

Singh, A. K. 2000. Species of honeybees and their importance. In: R. Singh, P. Kumari and H. Chand (eds.), Manual on honeybee management. Apiary Unit, Rajendra Agricultural University, Bihar, Pusa. pp 20-21.

Singh, S. 1962. Beekeeping in India. Indian Council of Agricultural Research, New Delhi. 214 pp.

Singh, Y. 1980. Beekeeping in Uttar Pradesh-A review. In: Proc. Intl. Conf. Apic. Trop. Climmate., 2:211-226.

Thakar, C.V. and K. V. Tonapi. 1961. Nesting behavior of Indian honeybees: Differentiation of worker, queen and drone cells of the combs of Apis dorsata Fab. Bee World. 42: 61-62, 71.

Thapa, R. 1998. Colony migration of the giant honeybee Apis dorsata Fab. Ph.D Dissertation. Chulalongkorn University, Thailand. 102 pp.

Wongsiri, S., R. Thapa, B. P. Oldroyd and D. M. Burgett. 1996. A magic bee tree. Home to Apis dorsata Fab. Am. Bee J., 136 (11): 796-799. 